\title{
OBSERVATIONS ON THE CHANGE FROM FOETAL TO ADULT ERYTHROPOIESIS
}

\author{
BY \\ I. D. FRASER and A. B. RAPER \\ From the Department of Pathology, United Bristol Hospitals, and the Department of Child Health, \\ University of Bristol
}

(RECEIVED FOR PUBLICATION JANUARY 2, 1962)

The replacement of foetal haemoglobin $(\mathrm{Hb} \mathrm{F})$ by the adult form ( $\mathrm{Hb} \mathrm{A}$ ) in the circulating blood of an infant is a striking event, but its mechanism is incompletely understood. The dramatic cessation of haemopoiesis in the liver at about the time of birth coincides roughly with the time when $\mathrm{Hb} \mathrm{F}$ begins to disappear most rapidly from the peripheral blood; and it is not surprising that some writers, most recently Langley (1951) and Brody (1959), have taken the view that the two events are closely connected, and assume that $\mathrm{Hb} F$ production is limited to the liver, and $\mathrm{Hb} \mathrm{A}$ production to the marrow. This view would require that the change-over was the result of the emergence and ultimate domination of erythrocyte precursors in the marrow which, because of their genetic equipment or their environment, were from the start capable only of the adult type of haemoglobin synthesis.

Such an interpretation is not acceptable to all, however, and the view is gaining ground that the two types of haemoglobin molecule can be synthesized by normoblasts in each of the main anatomical sites of erythropoiesis. One requirement of this view-that a single normoblast can manufacture two types of molecule-is met by the undoubted facts that whenever $\mathrm{Hb} \mathrm{S}$ occurs with another $\mathrm{Hb}$ type, both haemoglobins are present in the same cell, since all the cells can be made to undergo sickling; and that in adults who are heterozygous for the normal and for the 'high-F' gene, $\mathrm{Hb} F$ is demonstrable in every erythrocyte, and therefore each must contain both $\mathrm{Hb} \mathrm{F}$ and $\mathrm{Hb} \mathrm{A}$ (Thompson, Mitchener and Huisman, 1961). On this second view the change-over would be explained by the progressive maturation of the intracellular enzyme systems concerned in synthesis, taking place at about the time of birth in all erythropoietic cells whatever their site, so that successive generations of normoblasts would manufacture more $\mathrm{Hb} \mathrm{A}$ and less $\mathrm{Hb} \mathrm{F}$.

The main difficulty in the past has been that it has only been possible to study the $\mathrm{Hb} F$ and $\mathrm{Hb} \mathrm{A}$ content of the blood in bulk, and to relate the proportions of the two types of haemoglobin in the whole peripheral blood to the actual mass of erythropoietic tissue in the viscera and marrow respectively. This gives only a very general correlation; the amount of $\mathrm{Hb} \mathrm{F}$ in the blood is reduced from about the time that the mass of blood-forming tissue in the marrow exceeds that in the viscera (Custer, 1949). Consequently other methods have been sought.

Attempts have been made to determine whether different proportions of $\mathrm{Hb} \mathrm{F}$ exist in blood withdrawn from the liver and marrow respectively in the perinatal period (Jonxis, 1949; Schulman, 1959). These have not yielded any definite result, as might indeed be expected, since aspiration at either site is liable to sample not only the blood formed locally, but also much mixed peripheral blood. The critical fact, if it could be determined, is what type of haemoglobin is present in the local normoblasts that have not yet entered the circulation.

A more promising way of investigating the synthetic activity of haemopoietic cells is to study them in culture in vitro. Thomas, Lochte, Greenhough and Wales (1960) incorporated glycine containing ${ }^{14} \mathrm{C}$ in liver, spleen and marrow cells from a 17 -week foetus by incubating them for 24 hours in vitro. They then separated haemoglobins $A$ and $F$ from a haemolysate of the cells by the device of adding a proportion of 'carrier' $\mathrm{Hb} \mathrm{A}$. By determining the specific activity of the two fractions obtained by electrophoresis, they were able to estimate the relative capacities for forming the two haemoglobin types for cells from each of the three sites. Relatively more $\mathrm{Hb} \mathrm{F}$ was produced by cells from the liver and spleen than by those from the marrow; nevertheless, the bone marrow produced 1.8 times as much $\mathrm{Hb} \mathrm{F}$ as $\mathrm{Hb} \mathrm{A}$, and the viscera of this foetus, and of a 9-week foetus, produced $\mathrm{Hb} \mathrm{A}$ in amounts varying from $1 / 4 \cdot 8$ to $1 / 2 \cdot 3$ of the $\mathrm{Hb} F$ manufactured. Perhaps these results, especially the last- 
mentioned, somewhat exaggerate the capacity of the foetal liver to synthesize $\mathrm{Hb} \mathrm{A}$, since they do not accord with the low proportion of $\mathrm{Hb} \mathrm{A}$ in the blood of foetuses of this age; but if the conditions of the experiment can be accepted, its result suggests that each type of haemoglobin can be synthesized in both the viscera and the marrow.

It has recently become possible to identify red cells that contain $\mathrm{Hb} \mathrm{F}$, and this has opened the way to determining the $\mathrm{Hb} \mathrm{F}$ content of individual cells as they take their place in the circulation before and during infancy. Kleihauer, Braun and Betke (1957) showed that the haemoglobin of adult red cells could be eluted by a buffer at $p \mathrm{H} 3 \cdot 4$ to $3 \cdot 6$, while that of most cord cells could not. These authors believed that those cells in cord blood that retained their haemoglobin after exposure to this form of lysis were foetal cells, and this interpretation has been generally accepted (Zipursky, Hull, White and Israels, 1959; Swarup, Ghosh and Chatterjea, 1960; Mitchener, Thompson and Huisman, 1961), being supported by the observations that red cells in early foetuses are uniformly 'foetal', and that foetal cells cannot be found in adult blood except when an accidental foeto-maternal leak has occurred around the time of parturition (Zipursky et al., 1959; Finn, Clarke, Donohoe, McConnell, Sheppard, Lehane and Kulke, 1961; Apley, Colley and Fraser, 1961). The original observers (see also Betke and Kleihauer, 1958) adopted the view that partial retention of haemoglobin, which they observed in some cells in cord blood after hydrolysis, indicated that both haemoglobins A and F had been present in the cells, and also that the phenomenon they observed was due to the properties of the haemoglobin rather than of the cell membrane. Some evidence in support of this was that a haemolysate of adult blood applied to a filter paper could be dissolved by the buffer while a haemolysate of cord blood could not.

Several recent writers, amongst them Zuelzer and Robinson (1961a), agree that these partially hydrolysed cells, which we designate 'intermediate cells', contain both types of haemoglobin and that the method of Kleihauer et al. (1957) allows one to visualize the $\mathrm{Hb} F$ content of individual red cells. It appeared to us that a study of these cells in the perinatal period, which should relate their appearance and disappearance to other events before and after birth, could give information about the change from foetal to adult erythropoiesis-its time of occurrence, whether it was a sudden or a gradual process, and perhaps what the contribution of each haemopoietic site was.

Methods
Acid Hydrolysis. The original technique of Kleihauer et al. (1957) was followed. Dried methanol-fixed blood smears were immersed for 90 seconds in a 0.17 -molar citric acid-phosphate buffer at $37^{\circ} \mathrm{C} ., p \mathrm{H} 3 \cdot 4$. They were then rinsed in distilled water and stained with May-Grünwald stain for three minutes.

A differential count was performed on 500 erythrocytes in the treated films, classifying cells as foetal (fully haemoglobinized), intermediate (partially haemoglobinized), or adult (no stainable pigment present). Foetal cells are easily distinguishable from adult cells by the use of buffers of $p \mathrm{H}$ either below or above $3 \cdot 4$, but partial hydrolysis is much more sensitive to $p \mathrm{H}$ changes, becoming more complete as the $p \mathrm{H}$ is lowered. Consequently each batch of buffer used was adjusted to a $p \mathrm{H}$ of exactly $3 \cdot 4$, so that counts on intermediate cells in all samples should be comparable. Further, all the counts recorded below were made on films fixed and processed within 24 hours of collection, usually much less, since delay modifies the resistance of dried erythrocytes.

Foetal Haemoglobin. This was determined by the Singer one-minute method, except in the case of early foetal samples and the cord blood of babies born before the 36th week of gestation; for these the method of White and Beaven (1954) was used.

\section{Material}

Blood was obtained from seven foetuses by intracardiac puncture within one hour of expulsion from the uterus, and from the umbilical cord of 530 babies of gestational ages ranging from 34 to 40 weeks. Single heel-prick samples of blood were taken from 80 normal babies aged 1 to 42 weeks; and 111 similar samples were obtained from premature babies attending a follow-up clinic between the ages of 2 and 32 weeks. In a further 10 normal babies, capillary samples were obtained at two-week intervals from each baby from birth to the age of 30 weeks.

\section{Results}

Prenatal Samples. The foetuses examined were of 13 to 20 weeks' gestation. In none of these could any but typical foetal erythrocytes be detected. Adult haemoglobin appeared in a chemically measurable amount in a foetus of 16 weeks, and in slightly greater amount in the 18 and 20-week foetuses, in agreement with the findings of Walker and Turnbull (1955). But even at 20 weeks, when about $8 \%$ of $\mathrm{Hb} \mathrm{A}$ was present, the cells remained fully foetal in staining properties (Fig. 1).

In premature and pre-term babies intermediate cells had appeared in the youngest infant examined (34 weeks' gestation). Our results do not establish the earliest time of appearance of these cells, except that by extrapolation of the curve in Fig. 1 it may be supposed to be at about the 31st week of gestation. They do, however, show that adult cells appear in very small numbers at the 37 th and 38 th 
weeks, and have amounted to $4 \%$ of the red cell population at birth.

Normal Neonatal Samples. Fig. 2 records the findings in 10 normal babies on whom consecutive counts were made. (In the 80 normal babies examined on separate occasions, the results were closely similar.) The proportion of wholly foetal cells declined steeply after birth, and these cells were not seen after the sixteenth week of life. Intermediate cells, forming $20 \%$ of the erythrocyte population at birth, increased to a maximum at the eighth week, when they were the most numerous cells in the blood. Their proportion then declined to $1 \%$ at 30 weeks. (An occasional intermediate cell was seen at ages from 30 to 36 weeks in the 80 babies mentioned above, but none thereafter.)

It will be observed in Fig. 2 that while the percentage of chemically-determined $\mathrm{Hb} \mathrm{F}$ at first follows closely the percentage of foetal cells, the curves separate after the fourth week. From this time onwards the $\mathrm{Hb} \mathrm{F}$ content of the whole blood exceeds its content of foetal cells, and now follows a curve midway between those for foetal and intermediate cells respectively. Finally, when foetal cells have disappeared, $\mathrm{Hb} \mathrm{F}$ is still found in amounts that decline in parallel with the fall in intermediate cells.

Samples from Premature Babies. Each curve in Fig. 3 represents the average findings in a group of premature babies; individual babies were not followed as in Fig. 2. The ages given are the intervals in weeks from the actual time of birth for babies born at the 35th, 36th and 37th week of gestation. A chemical determination of $\mathrm{Hb} F$ was not made in these cases. Initially, as expected, foetal cells were less numerous the greater the gestational age at birth and, falling at about the same rate in the three groups, they tended to disappear earlier (i.e. sooner after birth) in the less premature babies. Likewise, adult cells rose earlier in the less premature babies. Corresponding with these changes, intermediate cells rose earlier and fell earlier in the less premature babies. Complete smoothness and regularity could not be expected in these curves, obtained as they were without following events in sequence in individual babies; nevertheless, it is evident that an approach to a fit with the 37-week curve would be achieved by transposing the 36-week curve back one week, and the 35-week curve back two weeks. It follows that the events which they represent are more closely related to gestational age than to age reckoned from the time of birth.

The relation is not complete, however. Fig. 4

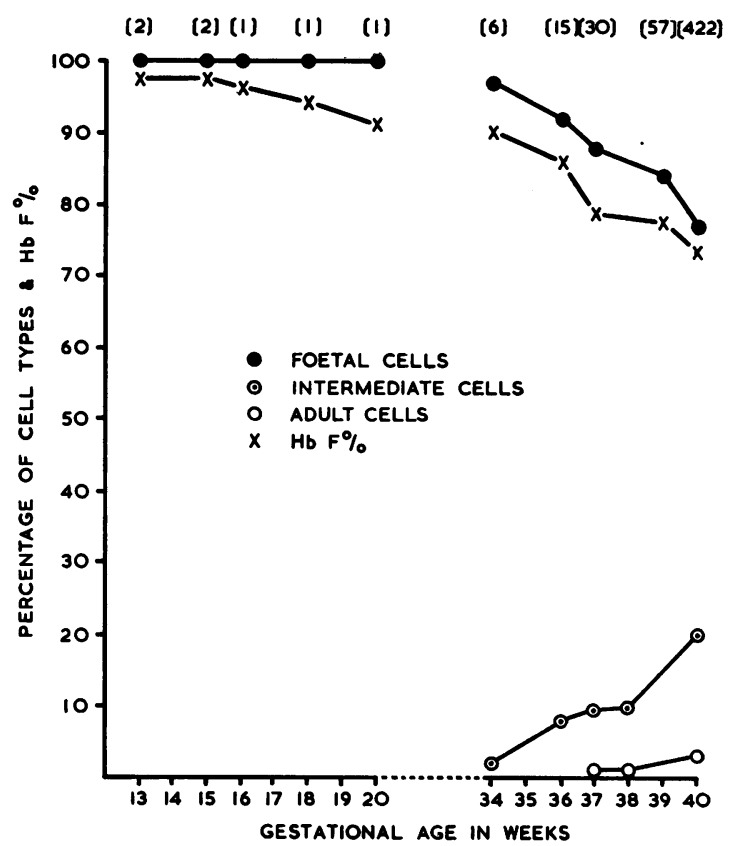

FIG. 1.-Proportions of foetal, intermediate and adult red cells, and of $\mathrm{Hb} \mathrm{F}$, in the blood of seven foetuses and the cord blood of 530 babies born from the 34th to the 40th week of gestation. Figures in parenthesis indicate the number of observations.

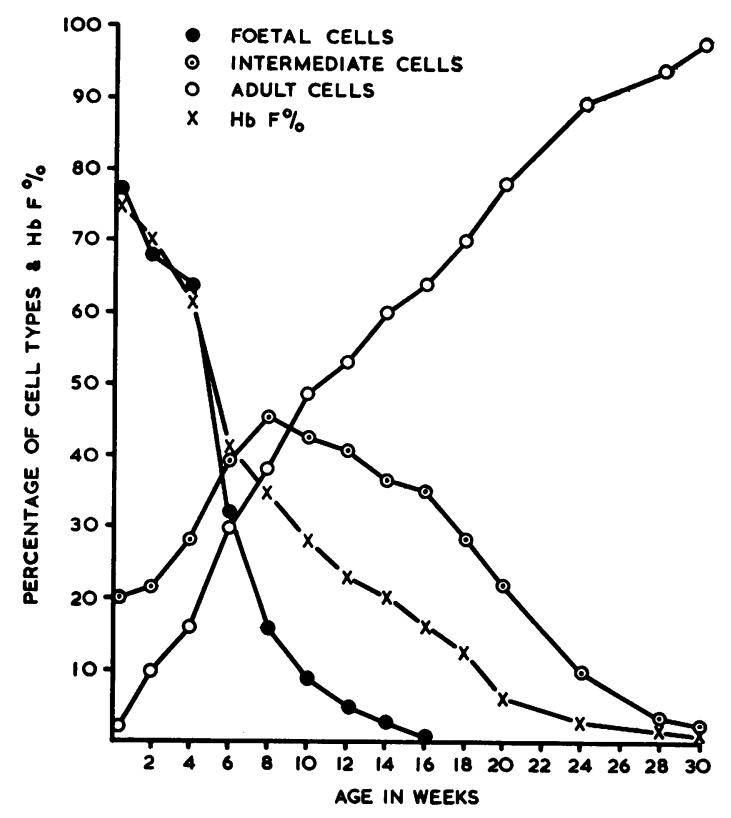

FIG. 2.-Proportions of foetal, intermediate and adult red cells, and of $\mathrm{Hb} \mathrm{F}$, in serial specimens of blood from 10 normal babies. 


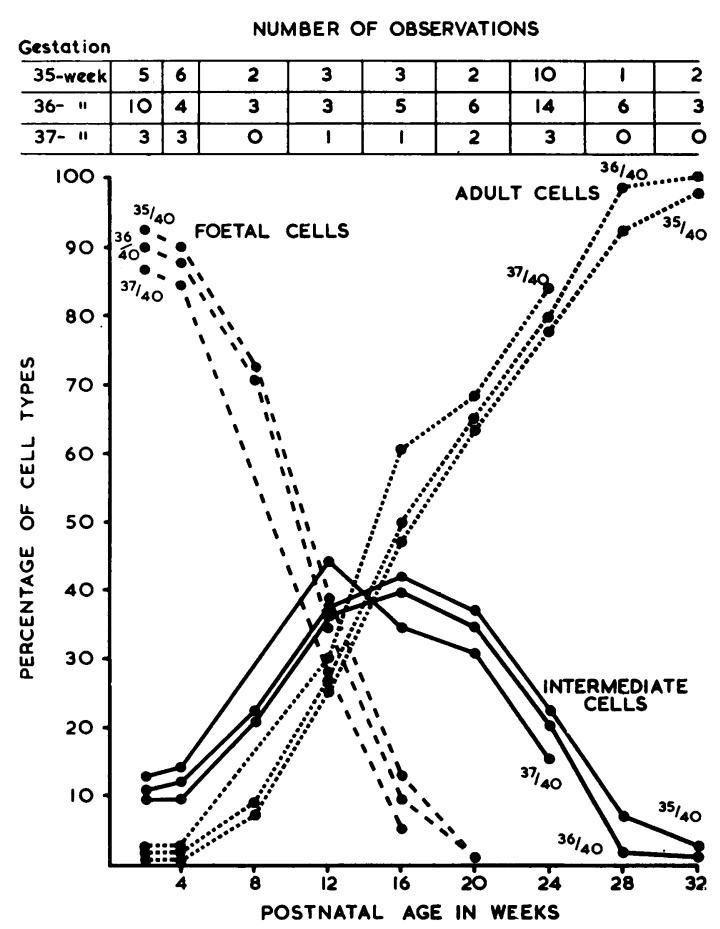

FIG. 3.-Postnatal changes in erythrocyte types in babies of varying degrees of prematurity.

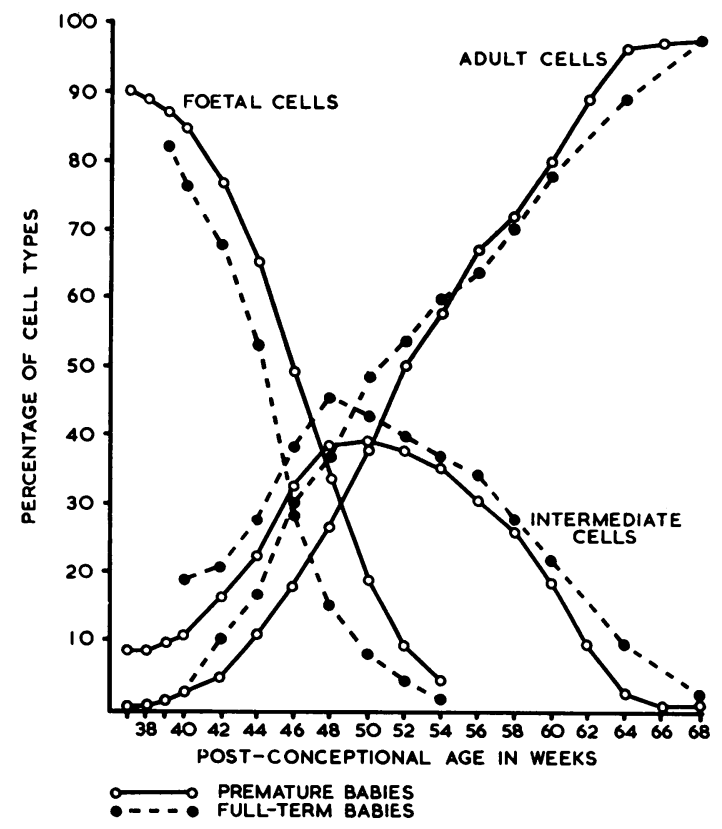

FIG. 4.-Postnatal changes in erythrocyte types according to postconceptional age. shows (1) the distribution of the cells in full-term babies of various ages, as in Fig. 2, and (2) curves for the premature babies. The latter are for the same babies as shown in Fig. 3, but each point represents an average of the findings for babies of the same post-conceptional age. It is clear that the postnatal changes in these premature babies are not the same as in full-term babies of the same gestational age. Foetal cells tend to persist in larger proportions, though they finally disappear at about the same time as in the normal babies; and the rise in intermediate and adult cells is delayed.

\section{Discussion}

Analysis of Results. By the 20th week of gestation of a human foetus, some non-alkali-resistant haemoglobin has been formed (Fig. 1). It has been accepted that this is in fact $\mathrm{Hb} \mathrm{A}$ (Beaven, Ellis and White, 1960; Butler, Flynn and Huehns, 1960). Its proportion (about $8 \%$ in our series) shows little change until the 34th week, a result similar to those of Walker and Turnbull (1955) and Beaven, Hoch and Holiday (1951); and neither before nor at the end of this period can its presence in the foetal red cells be detected visually by the use of the acid hydrolysis test, presumably because it is distributed equally or nearly equally between the cells in amounts so small that its extraction (if it occurs) makes no visual difference to the appearance of the stained cells.

A change occurs just before the 34th week of gestation. The $\mathrm{Hb} \mathrm{A}$ content of the blood begins to rise, and at the same time intermediate red cells appear which, if our interpretation of the acid hydrolysis test is correct, contain some $\mathrm{Hb} \mathrm{A}$. These cells increase in numbers, and the $\mathrm{Hb} \mathrm{A}$ content of the blood continues to increase for at least three weeks before any completely adult cells appear, confirming the view that the intermediate cells must contain $\mathrm{Hb} \mathrm{A}$ as well as $\mathrm{Hb} \mathrm{F}$. Truly adult cells appear for the first time at the 37th week (Fig. 1), but do not start to increase rapidly until the time of birth (Fig. 2).

Foetal cells are last recognizable in the peripheral blood in the sixteenth week of life, and intermediate cells at about the 32nd week. Mollison (1956) believed that the available evidence indicated that the life-span of red cells in a newborn baby was equal to, or only slightly less than, that of adult cells. Assuming therefore that the life-span of red cells in our cases was 15 to 16 weeks, some few foetal cells may be supposed to enter the circulation during the first week after birth, and the last cells to contain any visually demonstrable $\mathrm{Hb} F$ are produced at the sixteenth to seventeenth week of 

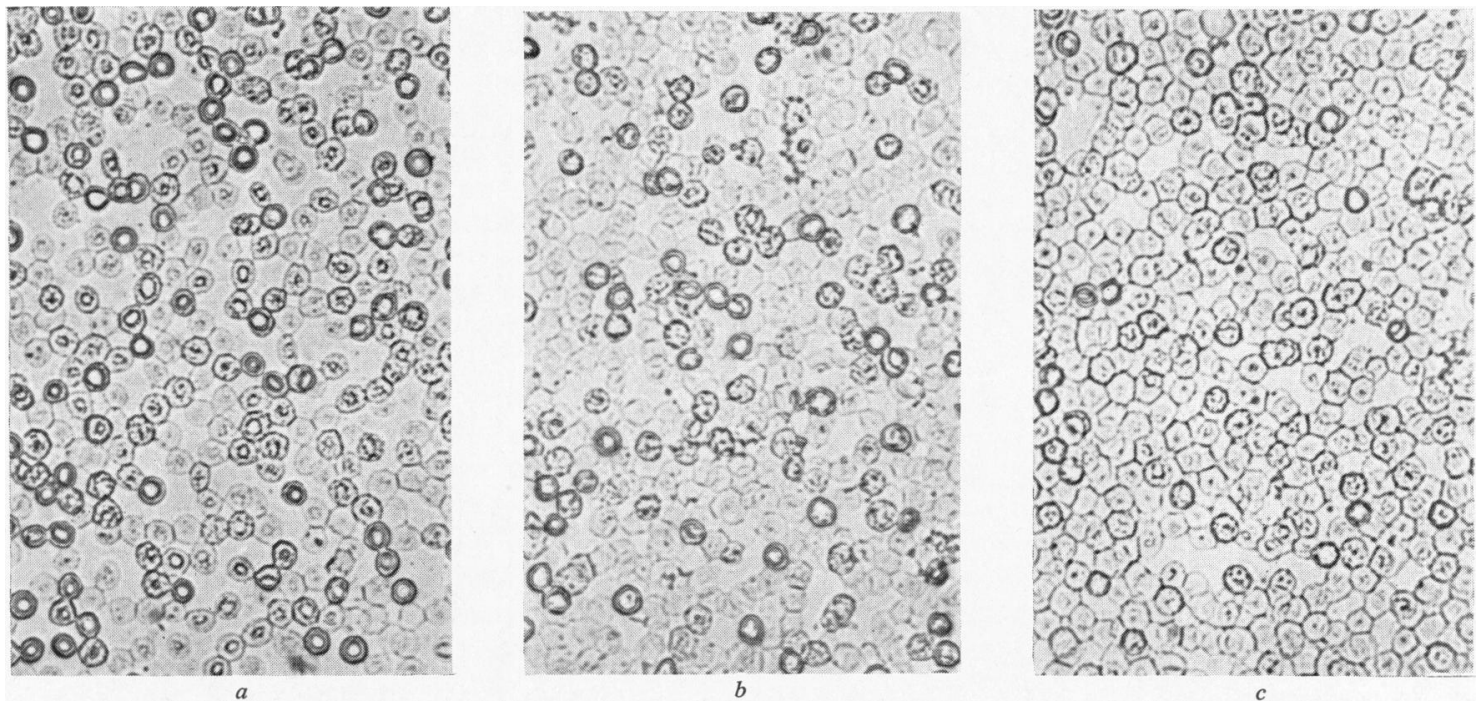

FIG. 5.-Dried fixed blood films, lysed at $p \mathrm{H} 35$, and photographed unstained. Refractility is dependent on $\mathrm{Hb}$ retention. $a$, from 6-week baby; $b$, from 11-week baby; $c$, from 19-week baby. Note the many refractile cells in $a$, with about equal numbers of partly refractile intermediate cells. The latter are less refractile in $b$ and much less so in $c$.

life. It may be noted that during the last few weeks in which these intermediate cells are demonstrable, their content of $\mathrm{Hb} \mathrm{F}$, as judged by their uptake of stain or their refractility after acid hydrolysis, is very much less than when they first appear; and in fact during the 22 weeks in which they can be seen their apparent content of $\mathrm{Hb} \mathrm{F}$ declines in a manner that can easily be appreciated visually though not readily measured (Fig. 5). That they do in fact contain $\mathrm{Hb} \mathrm{F}$ is shown by the persistence of alkaliresistant haemoglobin in the blood after the sixteenth week when only adult and intermediate cells are present, and by its virtual disappearance at the same time as the intermediate cells disappear. It is safe to conclude, therefore, that smaller and smaller proportions of $\mathrm{Hb} \mathrm{F}$ are incorporated into successive generations of these intermediate cells.

Anatomical Basis of Erythropoiesis. The anatomical sites of haemopoiesis during foetal, perinatal, and adult life are well known (Gilmour, 1941; Langley, 1951; Wintrobe, 1956). We have now to attempt to allocate the three types of cell we have described to the organs in which they may originate. We have to admit that we still cannot furnish a complete account; one reason is that we have been unable to make preparations to demonstrate with accuracy the $\mathrm{Hb} F$ and $\mathrm{Hb} \mathrm{A}$ content of normoblasts in the liver and marrow at various ages. However, the relevant data from the preceding discussion may be summarized as follows: $\mathrm{Hb} \mathrm{A}$ can be produced in small amount from the sixteenth week of gestation; by the 32 nd to 34 th week it has begun to be incorporated in increasing amounts (together with $\mathrm{Hb} \mathrm{F}$ ) in an increasing number of new erythrocytes; the first wholly adult cells appear some three weeks before birth; and $\mathrm{Hb} \mathrm{F}$ continues to be incorporated in decreasing amounts in new erythrocytes until about the sixteenth week of extrauterine life. It should be noted that Figs. 1 to 4 express the proportions of the various types of erythrocyte existing in the blood at any moment, and because the blood volume in the perinatal period is rapidly expanding there is no simple way of deriving from these curves the relative rates of production of the three types of cell at any moment. Fig. 6, which summarizes the changes detailed above,

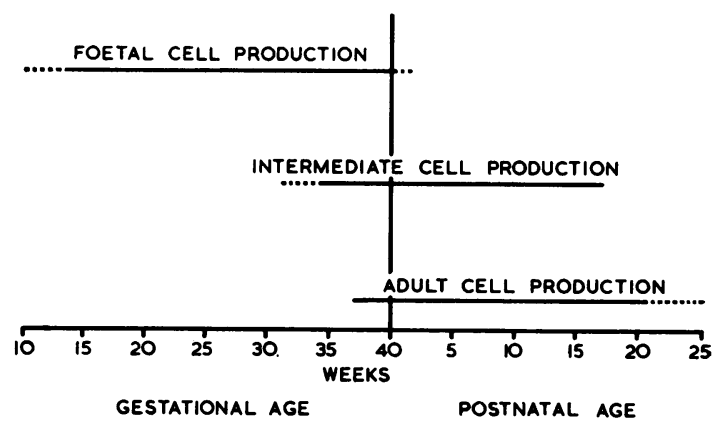

FIG. 6.-Diagrammatic representation of duration of production of foetal, intermediate and adult erythrocytes from observed first appearance to estimated time of final production. 
confines attention to the first and last appearance of each type, and it is from the facts that it expresses that the firmest conclusions about changes in erythropoiesis can be drawn.

Before the twelfth week of gestation, when the bone marrow is inactive, only foetal cells appear in the blood, and these cells contain almost wholly $\mathrm{Hb} \mathrm{F}$; this type of cell must represent the contribution of the visceral centres of blood formation up to this time. From the twelfth to just before the 34th week the cells are tinctorially foetal, but the haemolysate contains measurable amounts of $\mathrm{Hb} \mathrm{A}$, and the amount does not significantly change during the period. All this time the liver is actively erythropoietic, but marrow activity begins at about the 20th week and increases rapidly, so that by the 34th week the marrow is the predominant source of new red cells, and by this time it may be estimated to have contributed about $25 \%$ of the circulating blood. If the marrow had contributed any adult type cells, these should be visible. On the contrary, at the 34 th week there are no adult and only very scanty intermediate cells. These latter may or may not have come solely from the marrow. But the vast majority of cells are of foetal type, though containing a small amount of $\mathrm{Hb} \mathrm{A}$; and because of the near uniformity of their product, we must conclude that up to this time both organs can manufacture some $\mathrm{Hb} \mathrm{A}$ though their chief product is $\mathrm{Hb} \mathrm{F}$.

Consideration of events just before and just after birth may be deferred for the moment. After the first week of life, when the marrow is the sole organ of erythropoiesis, we know that no more typical foetal cells are formed. Yet $\mathrm{Hb} \mathrm{F}$ is still produced, and is incorporated together with $\mathrm{Hb} \mathrm{A}$ in the intermediate cells. These cells must come from the marrow at this time, and must continue to do so until their output ceases at about the sixteenth week of life; and successive generations of these cells from the marrow contain less and less $\mathrm{Hb}$ F. Thus, up to six weeks before birth the marrow can manufacture large quantities of $\mathrm{Hb} \mathrm{F}$ and after the first week of life can produce declining amounts of this haemoglobin. It is, therefore, reasonable to conclude, though we have no absolute proof, that during the intervening perinatal period the capacity of the marrow to produce $\mathrm{Hb} \mathrm{F}$ is similarly declining. While considering neonatal events, we may remark that wholly adult cells appear at about three weeks before birth, and their subsequent rapid increase in the circulation shows that very soon after birth they are the main cell type formed; yet for a time the marrow produces both adult and intermediate cells.
The activity of the liver cannot be defined so precisely as that of the marrow. From the 20th to just before the 34th week of foetal life we have argued that its output of cells, characteristically foetal, is yet the same as that of the marrow during this period. From the 34th week until liver activity ceases, we have as yet no means of recognizing cells of specifically hepatic origin, nor indeed of saying whether some of the foetal cells formed in this period may not have come from the marrow. We are thus left in doubt as to whether the liver can produce only foetal cells, or whether it is beginning, in the perinatal period, to turn to the manufacture of more $\mathrm{Hb} \mathrm{A}$, as the marrow does. Satisfactory observations on hepatic normoblasts would be of great importance in this connexion.

The normal cessation of liver haemopoiesis robs us of the opportunity of observing whether the liver, if it should remain active after birth, would, as does the marrow, synthesize $\mathrm{Hb} \mathrm{A}$ in increasing amounts. Pathological conditions may throw some light on this question. Extramedullary erythropoiesis in adult life (e.g. in myelosclerosis) is not accompanied by a significant rise in $\mathrm{Hb} \mathrm{F}$ synthesis. Nearer to the time of birth, events in icterus gravis neonatorum are relevant. When a severely erythroblastotic baby is born, the $\mathrm{Hb} \mathrm{F}$ content of the blood may be $60 \%$, and the proportion of foetal cells $55 \%$. After exchange transfusion these figures will fall to about $10 \%$ and $7 \%$ respectively. In the subsequent two to three weeks, haemopoiesis is active, and the liver must share in this for several days at least, for it is known to contain a large mass of erythropoietic tissue at birth in these babies (Gilmour, 1944). In some cases the product of this postnatal erythropoiesis is such that the $\mathrm{Hb} \mathrm{F}$ rises from $10 \%$ to about $18 \%$, but no rise in foetal cells occurs, indeed their numbers decline, and the increment in $\mathrm{Hb} \mathrm{F}$ is caused by a rise in the output of intermediate cells (Fraser, 1961). It is possible, though not proved, that some of these cells come from the liver; certainly no truly foetal cells result from whatever hepatic blood formation there may be. It seems therefore that erythropoiesis in the liver is destined to change qualitatively at about the time of birth, but that in normal circumstances this cannot be observed because of the coincident cessation of haemopoiesis in the liver.

The reverse situation may be seen in premature babies after birth. In these babies haemopoiesis in the liver extends for a longer period after the actual birth than in normal babies-an average of 18 days as compared with eight days (Langley, 1951) - but it usually ceases before the gestational age of 40 weeks is reached, and so hepatic blood 
formation has been out of action for a longer period in a premature baby than in a normal baby of the same gestational age. If the liver produced only foetal cells, there should be fewer of these in the circulation of premature babies than in normal babies of the same degree of maturity. Fig. 4 shows that the reverse is true. The explanation is probably that the haemopoietic activity of the marrow in prematurely born babies is depressed for a time (Schulman, Smith and Stern, 1954). This would reduce the influx of new cells (mostly intermediate and adult) in the neonatal period, and consequently even if no more foetal cells were formed, their percentage in the blood would be greater than in normal babies. This is quite sufficient to account for the findings illustrated in Fig. 4. Further, since the last foetal cells are to be found at about the same stage of maturity in both normal and premature infants, they are probably last produced at about the 41st week of gestational age, no matter when actual birth occurred. The effect of premature birth, therefore, is to impede postnatal haemopoiesis for a time, but not to alter it qualitatively.

Thus, as a whole, our findings are consistent with the view that it is not necessarily the anatomical site of origin that determines what type of cell and what type of haemoglobin will be produced. The liver and bone marrow are each capable of producing both $\mathrm{Hb} \mathrm{F}$ and $\mathrm{Hb} \mathrm{A}$, and of incorporating them in the same cell; they may perhaps manufacture these two haemoglobins in somewhat different proportions, but the most important influence, determining the product of both these organs, is the degree of development of the foetus.

Gene Activity and Haemoglobin Production. The close relation between gene activity and the synthesis of haemoglobin molecules is now beyond doubt. The work of Ingram and Hunt (1959) makes it possible to conceive of the gene as a determinant of a template for the orderly synthesis of the two polypeptide chains (the $\alpha$ - and $\beta$-chains) of the molecule from the necessary amino acids, and, as far as rabbit haemoglobin is concerned, Dintzis (1961) has produced evidence that the peptide chains grow by a steady sequential addition of amino acids. The final step in the synthesis of adult haemoglobin, suggested by Itano and Robinson (1959), is the combination of two sub-units each consisting respectively of two $\alpha$ - and two $\beta$ chains (Raper, Gammack, Huehns and Shooter, 1960). Hb F consists of two $\alpha$ - and two $\gamma$-chains. The change from foetal to adult haemoglobin synthesis must therefore be seen as a change from the capacity to form $\gamma$ chains to the capacity to form $\beta$-chains, the $\alpha$-chains being manufactured throughout.

Zuelzer and Robinson (1961a) have argued that the same genetic locus controls at first the synthesis of $\gamma$-chains and later that of $\beta$-chains, and suggest that "on this hypothesis the "switch-over" from haemoglobin $\mathrm{F}$ to haemoglobin $\mathrm{A}$ in the normal foetus can be viewed as the modulation of a single genetic effect, induced in the course of maturation, an event for which many precedents are known in the behaviour of enzymes and hormones'. The argument that a single gene locus is involved has been criticized by Ingram (1961), but Zuelzer and Robinson (1961b) point out that by a minor modification in its statement their theory can be adapted to Ingram's premises. For our purpose it matters little whether the change is viewed as the modification of a single gene, or as the supervention of a hitherto inactive second gene; the important point is that it is becoming increasingly difficult to conceive of haemoglobin synthesis except as a process ordered by genecontrolled templates within the cell. A change in the type of synthesis therefore means a change in the effective genetic equipment of the cell. If we accept this view, there is no difficulty in imagining the process as a gradual one, becoming more complete in the progeny of successive generations of erythrocyte precursors; indeed, any other explanation of the diminishing content of $\mathrm{Hb} \mathrm{F}$ in intermediate cells would be much less satisfactory. But we have to admit that the appearance of fully adult cells while intermediate cells are still being formed makes it likely that maturation occurs earlier in some clones of cells than in others. However, this is quite conceivable, and it is a better explanation than the other possibilities. For example, the whole change-over cannot be explained as a 'take-over' by a new clone of cells, for this leaves unexplained the gradual change in the intermediate cells; nor can the change to pulmonary respiration be accepted as the determining factor, because adult cells appear well before this event. Thus on the whole our findings agree with the concept that both liver and bone marrow are capable of responding to the general maturation of the foetus by a corresponding maturation of the enzyme systems controlled by the $\beta-\gamma$ loci.

Our results suggest that there are two periods in foetal life when a change in the type of activity of the $\beta-\gamma$ loci can be detected; just before the 20th week, when a small but definite increase in $\mathrm{Hb} \mathbf{A}$ production occurs, and just before the 34th week, when the final change-over is set in motion. The fact that these steps correspond roughly (but, it 
should be noted, not exactly) with those of anatomical development does not mean that the one event directly determines the other; they may be coincidental effects of the underlying synchronized plan of development.

\section{Summary}

The individual red cells of a foetus or newborn child can be classified according to their reaction to acid hydrolysis as of foetal, intermediate, or adult type. Intermediate cells contain a mixture of haemoglobins $\mathrm{A}$ and $\mathrm{F}$.

Examination of blood from early and late foetuses and infants shows that

(a) foetal cells are last formed in the first week of life,

(b) intermediate cells appear before the 34th week of gestation and are last formed in the sixteenth week of life, and

(c) adult cells first appear at the 37 th week of gestation.

Evidence is given that the marrow can produce $\mathrm{Hb} \mathrm{F}$ in gradually declining amounts from the onset of its activity until the sixteenth week of life.

There are indications that the capacity of the liver to manufacture $\mathrm{Hb} \mathrm{A}$ increases in the perinatal period.

The change from foetal to adult erythropoiesis is a gradual one and is probably the result of a gene-controlled maturation of the intracellular synthetic mechanism.

We wish to thank Professor A. V. Neale and Dr. T. Oppé for their interest and help, and for permission to use their clinical material. We also wish to thank Professor J. M. Yoffey and Dr. D. B. Thomas for allowing us access to foetal material.

\section{REFERENCES}

Apley, J., Colley, P. A. N. and Fraser, I. D. (1961). Foetal haemorrhage into the maternal circulation. Lancet, 1, 1375 .

Beaven, G. H., Ellis, M. J. and White, J. C. (1960). Studies on human foetal haemoglobin. Foetal haemoglobin levels in healthy children and adults and in certain haematological disorders. Brit. J. Haemat., 6, 201.
—, Hoch, H. and Holiday, E. R. (1951). The haemoglobins of the human foetus and infant. Electrophoretic and spectroscopic differentiation of adult and foetal types. Biochem. J., 49, 374.

Betke, $K$ and Kleihauer, E. (1958). Fetaler und bleibender Blutfarbstoff in Erythrozyten und Erythroblasten von menschlichen Feten and Neugeborenen. Blut, 4, 241.

Brody, S. (1959). Foetal-type haemoglobin in the blood of the newborn. Lancet, 1, 520 .

Butler, E. A., Flynn, F. V. and Huehns, E. R. (1960). Haemoglobin of foetal blood. Clin. chim. Acta, 5, 571.

Custer, R. P. (1949). An Atlas of the Blood and Bone Marrow. Saunders, Philadelphia and London.

Dintzis, H. M. (1961). Assembly of the peptide of hemoglobin Proc. nat. Acad. Sci. (Wash.), 47, 247.

Finn, R., Clarke, C. A., Donohoe, W. T. A., McConnell, R. B. Sheppard, P. M., Lehane, D. and Kulke, W. (1961). Experimental studies on the prevention of $\mathrm{Rh}$ haemolytic disease. Brit. mea. J., 1, 1486.

Fraser, I. D. (1961). Thesis for the Degree of Doctor of Medicine,

Bristol University.
Gilmour, J. R. (1941). Normal haemopoiesis in intra-uterine and neonatal life. J. Path. Bact., 52, 25.

- (1944). Erythroblastosis foetalis. Arch. Dis. Childh., 19, 1.

Ingram, V. M. (1961). Haemoglobin $F$ and the genetic control of protein structure. Nature (Lond.), 191, 608.

and Hunt, J. A. (1959). Ciba Foundation Symposium on Biochemistry of Human Genetics, p. 114. Churchill, London.

Itano, H. A. and Robinson, E. (1959). Formation of normal and doubly abnormal haemoglobins by recombination of haemoglobin I with $S$ and C. Nature (Lond.), 183, 1799.

Jonxis, J. H. P. (1949). In Haemoglobin, p. 265, ed. F. J. W. Roughton and J. C. Kendrew. Butterworth, London.

Kleihauer, E., Braun, H. and Betke, K. (1957). Demonstration von fetalem Hämoglobin in den Erythrocyten eines Blutausstrichs. Klin. Wschr. 35, 637.

Langley, F. A. (1951). Haemopoiesis and siderosis in the foetus and newborn. Arch. Dis. Childh., 26, 64.

Mitchener, J. W., Thompson, R. B. and Huisman, T. H. J. (1961). Foetal haemoglobin synthesis in some haemoglobinopathies. Lancet, 1, 1169.

Mollison, P.' L. (1956). Blood Transfusion in Clinical Medicine. Thomas, Springfield, lllinois.

Raper, A. B., Gammack, D. B., Huehns, E. R. and Shooter, E. M. (1960). Four haemoglobins in one individual. A stı dy of the genetic interaction of $\mathrm{Hb}-\mathrm{G}$ and $\mathrm{Hb}-\mathrm{C}$. Brit. med. J., 2, 1257.

Schulman, I. (1959). In Oxygen Supply to the Human Foetus, p. 43, ed. J. Walker and A. C. Turnbull. Blackwell, Oxford. , Smith, C. H. and Stern, G. S. (1954). Studies on the anaemia of prematurity. A.M.A. J. Dis. Child., 88, 582 .

Swarup, S., Ghosh, S. K. and Chatterjea, J. B. (1960). Observations on the staining of foetal haemoglobin in blood smear. Bull. Calcutta Sch. trop. Med., 8, 53-54.

Thomas, E. D., Lochte, H. L., Jr., Greenhough, W. B. and Wales, M. (1960). In vitro synthesis of foetal and adult haemoglobin by foetal haematopoietic tissues. Nature (Lond.), 185, 396.

Thompson, R. B., Mitchener, J. W. and Huisman, T. H. J. (1961) Studies of the fetal hemoglobin in the persistent high $\mathrm{Hb}-\mathrm{F}$ anomaly. Blood, 18, 267.

Walker, J and Turnbull, E. P. N. (1955). Haemoglobin and red cells in the human foetus. III. Foetal and adult haemoglobin. Arch. Dis. Childh., 30, 111.

White, J. C. and Beaven, G. H. (1954). A review of the varieties of human haemoglobin in health and disease. J. clin. Path., 7, 175 .

Wintrobe, M. M. (1956). Clinical Hematology, 4th ed., p. 29. Lea and Febiger, Philadelphia.

Zipursky, A., Hull, A., White, F. D. and Israels, L. G. (1959). Foetal erythrocytes in the maternal circulation. Lancet, $1,451$.

Zuelzer, W. W. and Robinson, A. R. (1961a). Haemoglobin F: Its significance in the genetics and evolution of haemoglobin. Nature (Lond.), 190, 237.

- , - (1961b). Haemoglobin F and the genetic control of protein structure. ibid., 191, 509. 